\title{
The intertidal polychaete (Annelida) fauna of the Sitakunda coast (Chittagong, Bangladesh), with notes on the Capitellidae, Glyceridae, Lumbrineridae, Nephtyidae, Nereididae and Phyllodocidae of the "Northern Bay of Bengal Ecoregion"
}

\author{
Alexander I. Muir', Md. M. Maruf Hossain² \\ I The Natural History Museum, London SW7 5BD, United Kingdom 2 Institute of Marine Sciences and \\ Fisheries, University of Chittagong, Bangladesh \\ Corresponding author: Alexander I. Muir (aim@nhm.ac.uk) \\ Academic editor: C. Glasby | Received 20 March 2014 | Accepted 2 June 2014 | Published 23 June 2014 \\ http://zoobank.org/ODFBF99C-ABD6-45F2-B8CB-8B00364FCF42 \\ Citation: Muir AI, Hossain MdMM (2014) The intertidal polychaete (Annelida) fauna of the Sitakunda coast \\ (Chittagong, Bangladesh), with notes on the Capitellidae, Glyceridae, Lumbrineridae, Nephtyidae, Nereididae and \\ Phyllodocidae of the "Northern Bay of Bengal Ecoregion". ZooKeys 419: 1-27. doi: 10.3897/zookeys.419.7557
}

\begin{abstract}
Of seven species of polychaetous annelids collected from the intertidal zone of Sitakunda coast, Chittagong, Bangladesh, five were new records for the country. The seven are listed, with brief notes on these, some previously recorded! species and others housed in the collections of the Natural History Museum, London. Keys are given to the recorded species of Phyllodocidae, Nereididae, Lumbrineridae, Nephtyidae and Capitellidae of the "Northern Bay of Bengal Ecoregion", and to the recognised species of Glyceridae from the Bay of Bengal. The worms in this Ecoregion are subject to the outflows of the Irrawaddy, Ganges, Hooghly and Mahanadi Rivers, and many of them are known to be freshwater tolerant.
\end{abstract}

\section{Keywords}

Taxonomy, Polychaeta, new records, keys, Odisha, West Bengal, Myanmar

Copyright A.I. Muir, Md.M.M. Hossain. This is an open access article distributed under the terms of the Creative Commons Attribution License (CC BY 4.0), which permits unrestricted use, distribution, and reproduction in any medium, provided the original author and source are credited. 


\section{Introduction}

There has long been an emphasis on taxonomy in marine studies, for example Hedgpeth (1957) recommends that the first procedure in any ecological works or applied research with organisms is the exercise of systematics. No ecological investigation can be successfully carried out without a comprehensive knowledge of the taxonomy of faunal resources.

Polychaete annelids are a major group within the soft bottom macro-invertebrates (Gray and Elliott 2009) and comprise a diverse, abundant and ecologically significant functional component of the coastal ecosystem (Misra 1999). These worms are pivotal parts of food webs and form the central link between the sediment systems and higher predators. They are often diverse and highly abundant, especially in areas of anthropogenic stress (Gray and Elliott 2009) and they have diverse feeding strategies (Fauchald and Jumars 1979).

The polychaete fauna of Bangladesh is little studied, despite the importance of marine resources to the country. The largest identification works for the littoral and shallow-water polychaetes of the Indian Ocean area are Fauvel (1953) for the Persian Gulf to Myanmar and Day (1967) for southern Africa. Hartman (1974a, 1974b) is more concerned with deep water polychaetes. There have been many smaller publications on the polychaetes of India, Thailand and Ceylon/Sri Lanka since Fauvel (1953), but only a few for Bangladesh (Mahmood et al. 1993, Belaluzzaman 1995, Alam et al. 1996, Das and Reynolds 2003, Pramanik et al. 2009) and even fewer for Myanmar (one new species each in Kirtley 1994 and Glasby 1999, one re-described species in Böggemann 2002). The most relevant recent publications are probably Misra (1999) and Pramanik et al. (2009).

The present study therefore aims to provide further information on the taxonomy of polychaetes in Bangladesh waters at two sites on the Sitakunda Upazila coast, north of the city of Chittagong (see Table 1), one of which is affected by ship-breaking activity on the shore.

The "Northern Bay of Bengal Ecoregion" of the "Bay of Bengal Province" of the "Western Indo-Pacific Realm" was devised by Spalding et al.,2007, and it is shown in map form in Claus et al (2014). The ecoregion extends from between Ye and Dawei $\left(14.61^{\circ} \mathrm{N}, 97.90^{\circ} \mathrm{E}\right)$ in Myanmar/Burma to near Konark $\left(19.87^{\circ} \mathrm{N} 86.11^{\circ} \mathrm{E}\right)$ in Odisha/Orissa, India (Fig. 1), and reaches from the coastline to $370 \mathrm{~km}$ offshore (or

Table I. Details of the sampling sites.

\begin{tabular}{|c|c|c|c|}
\hline Site & Name \& location & Substratum & Remarks \\
\hline 1 & $\begin{array}{l}\text { Muradpur, } \\
22^{\circ} 35^{\prime} 02^{\prime \prime N} \\
91^{\circ} 34^{\prime} 09^{\prime \prime} \mathrm{E}\end{array}$ & $\begin{array}{l}\text { Silty-muddy with fine } \\
\text { grain of sand (towards } \\
\text { sea side) }\end{array}$ & $\begin{array}{l}\text { Relatively undisturbed site along with planted } \\
\text { (relatively high Organic Carbon and Organ } \\
\text { compared to other site) }\end{array}$ \\
\hline 2 & $\begin{array}{l}\text { Madambabirhat, } \\
22^{\circ} 30^{\prime} 56^{\prime \prime N} \\
91^{\circ} 43^{\prime} 44^{\prime \prime} \mathrm{E}\end{array}$ & Sandy cum muddy & $\begin{array}{l}\text { Highly polluted \& disturbed area due to Ship Breaking } \\
\text { Activities in intertidal zone of the coast (low OC \& OM) }\end{array}$ \\
\hline
\end{tabular}




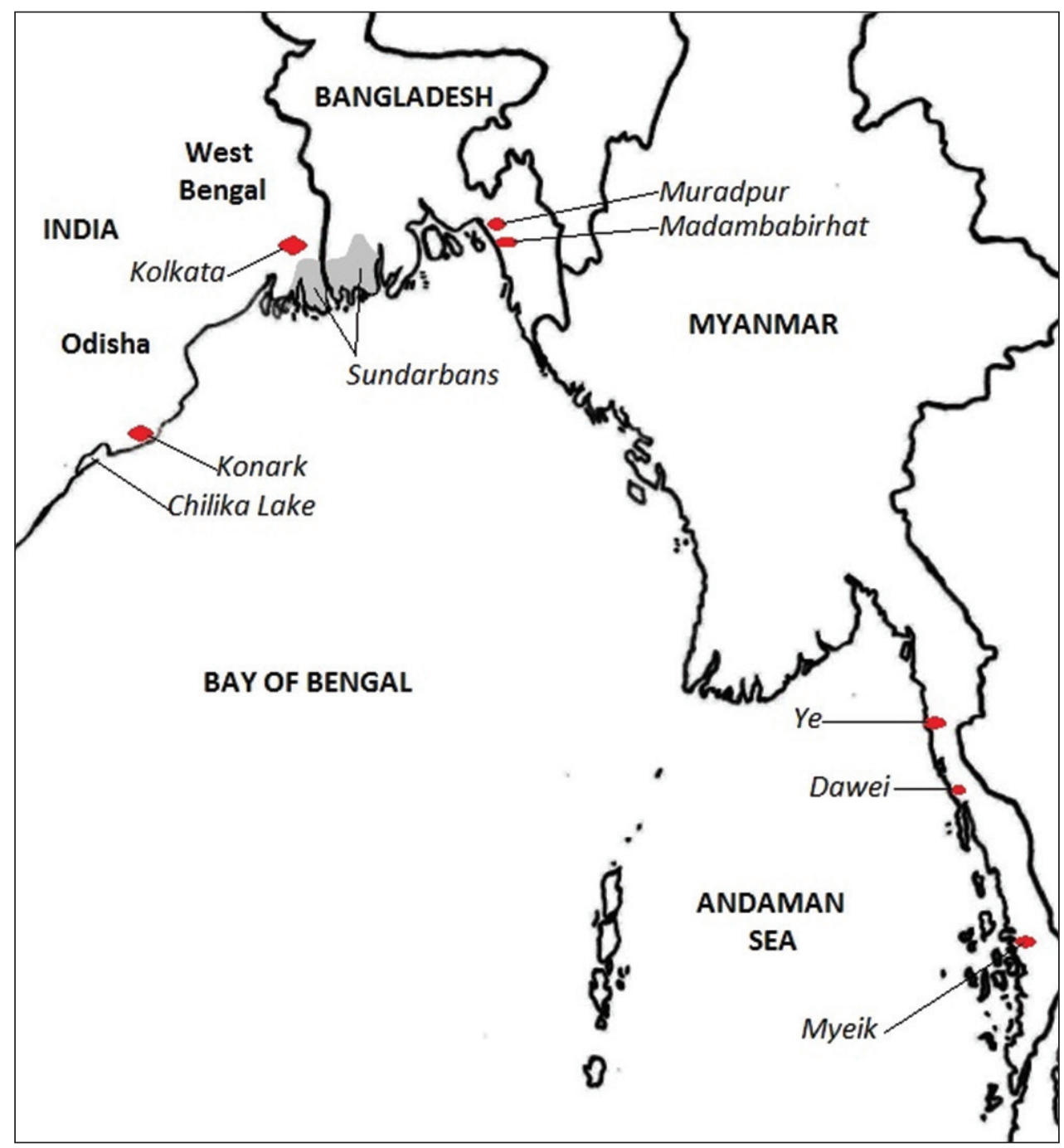

Figure I. Map of localities mentioned in the text.

the $200 \mathrm{~m}$ isobath if this is further offshore). It thus includes the Gulf of Martaban, the mouths of the Irrawaddy, Ganges and Hooghly Rivers, and most of the mouths of the Mahanadi River (one distributary leads to the Chilika Lake, usually referred to as Chilka Lake, which has its outlet to the sea in the neighbouring "Eastern India Ecoregion" of the "Bay of Bengal Province"). Southern Myanmar is in the "Andaman Sea Coral Coast Ecoregion" of the "Andaman Province".

In this paper, the new specimens from Bangladesh are compared with the same families of polychaetes reported from the "Northern Bay of Bengal Ecoregion", including the entire coast of Myanmar and the entire Odisha coast (to include the freshwater polychaetes of Chilka Lake). Important localities are shown in Figure 1. 


\section{Methods}

Quantitative samples were collected between April 2007 and November 2008, but the present paper only deals with the taxonomic details of polychaetes collected at those sites. Samples were collected from the intertidal zone by using a hand-held corer with a depth penetration of $15 \mathrm{~cm}$. The collected samples were washed through a $0.5 \mathrm{~mm}$ mesh hand sieve with filtered water at the collection point to separate animals from sediment. The materials retained on the sieve were placed in plastic vials to which 5\% formalin was added for fixing the organisms, and labelled. The vital stain Rose Bengal was added to the vials to help in sorting the organisms from debris. In the laboratory the materials were poured into a round transparent Petri dish and separated from debris using needle, brush and magnifying glass. Then the organisms were preserved in $75 \%$ ethyl alcohol for identification. An Olympus compound microscope with video facility was used and relevant keys (Fauvel 1953, Day 1967) were followed for preliminary identification. Identification to species necessitated the use of many other papers, which are mentioned later in this publication.

Because there are so few records from Myanmar, some specimens deposited in the Natural History Museum, London, by Professors G.E. Gates (Judson College, Rangoon) and F.J. Meggitt (University College, Rangoon) between 1931 and 1938, and only partially published by C.C.A. Monro $(1931,1937)$, have been re-studied.

Identification keys are given in this paper, but any identifications made using them should be checked against good descriptions or reliably identified specimens, because not only may new records or even new species be found, but some of the older reports cited here may have been mis-identifications or represent cryptic species (it is interesting that the type locality of Capitella capitata is West Greenland (Blake 2009), and for Glycera alba is Norway (Böggemann 2002)).

\section{Taxonomy}

\section{Annelida}

The taxonomy and systematics of the Annelida have been rapidly changing in recent years. It must be recognised that the classifications used in publications such as Fauvel (1953) and Day (1967) are now very dated. The fauna given in Fauvel (1953) shares many species with his earlier work on the fauna of France (Fauvel 1923, 1927), but it is not now considered likely that so many species from northern Europe would also be found in the Indian Ocean. A more modern classification (although still on classical lines) can be found in Chambers and Muir (1997). More strictly phylogenetic classifications are also available, such as Rouse (2000) and Appeltans et al. (2010). Keys to identify polychaetes to family level can be found in publications such as Fauchald (1977), Chambers and Muir (1997) and Glasby and Fauchald (2000). 
Polychaetous annelids are often regarded as a marine group (albeit with some freshwater tolerant species), but it should be noted that non-marine species also exist (see Glasby et al. 2009), including some from Bangladesh (Das and Reynolds 2003 list two species of Aeolosoma).

\section{Phyllodocidae}

\section{Eteone cf. delta Wu \& Chen, 1963}

One specimen was found: length $15 \mathrm{~mm}$, width $0.75 \mathrm{~mm}$ for 92 segments, but anal cirri missing. Anteriorly the height of the segments is $1 \mathrm{~mm}$, but posteriorly the body becomes dorso-ventrally flattened. This specimen has two pairs of tentacular cirri on the first segment, the dorsal being shorter than the ventral ones (they are both, however, small and difficult to see). The first chaetae are on the second segment. The pharynx is everted, showing a smooth surface and a ring of 12 large subglobular papillae around the opening (Fig. 2). The dorsal cirri are small and rounded, compressed against the side of the body. The ventral cirri, distally rounded, are almost as long as the chaetal lobe anteriorly, but slightly longer posteriorly. The tip of the acicula is just emergent from the chaetal lobe in the anterior part of the body, but in the posterior part of the body is much more protuberant. The specimen is colourless in alcohol except for some brown markings dorsally by the pygidium.

This specimen, especially the structure of the pharynx, displays similarities to Eteone delta Wu \& Chen, 1963, which is known from the Yangtze delta, the Pearl River and Zhangjiang estuary, China (Shen and Qi 1982, Chen et al. 2012). There are, however, differences such as the presence of emergent acicula. It is not considered advisable to describe this specimen as a species new to science, partly because there is only one specimen and partly because that specimen is incomplete (the shape of the anal cirri is important at the generic level for this group). It may be that this is a rare species which shows some morphological variation from one extreme of its geographic range to the other. Glasby et al. (2009) list Eteone delta as freshwater tolerant, found in the Palaearctic and Oriental regions inhabiting lake/river freshwater and estuary and coastal lagoons (fresh-brackish) including supra-littoral areas. Shen and Qi (1982) say it is "favored in normal or rich trophic waters", as opposed to over-trophic or polluted waters.

This is a new record for Bangladesh, no members of the family Phyllodocidae being recorded by Pramanik et al. (2009).

\section{Discussion of Northern Bay of Bengal Phyllodocidae}

Two specimens from Maungmagaun, Myanmar, in the Natural History Museum, London, (NHMUKANEA 1935.1.31.34 and NHMUK ANEA 1937.1.4.4) have been identified as Phyllodoce castanea by C.C.A. Monro. On both of these specimens many of the 


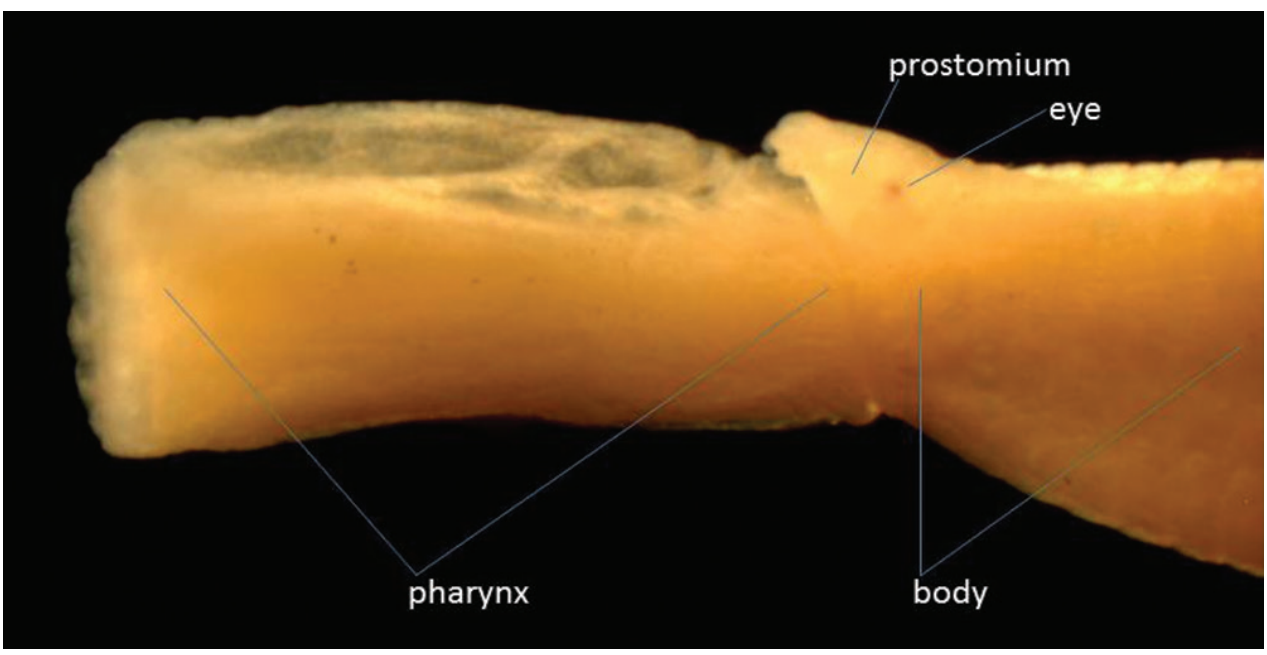

Figure 2. Lateral view of anterior end of Eteone cf. delta with pharynx extended.

head appendages are missing or regenerating, but the identifications are probably correct. The species is now known as Nereiphylla castanea (see synonymy in Alós et al. 2004). Fauvel (1932) records Phyllodoce madeirensis and Eulalia (Pterocirrus) magalhaensis from a depth of 2 fathoms $(3.658 \mathrm{~m})$ in the Mergui Archipelago.

Two species of Eteone are recorded from West Bengal (Misra 1999, Das et al. 2009, Mitra and Misra 2010). Eteone barantollae Fauvel, 1932, is now regarded as a member of the genus Hypereteone (see Wilson 1988). Eteone ornata Grube, 1878, has been referred to the genus Mysta, but may be a misidentification (Uschakov, in Wilson 1988).

In Odisha, Anaitides madeirensis, Eteone (Mysta) ornata and Eteone barantollae have been recorded from estuaries by Misra (1999) and Mitra et al. (2010). Anaitides madeirensis is now generally referred to as Phyllodoce madeirensis, and has a very wide distribution in temperate and tropical waters (Alós 2004).

These species from northern Bay of Bengal waters can be keyed out as follows, but any identifications must be checked against reliable descriptions as many other species are known from the Indo-Pacific area.

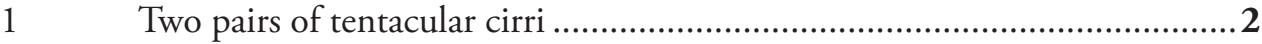

- Four pairs of tentacular cirri............................................................4 4

2 Pharyngeal surface smooth, but terminates in a ring of 12 large subglobular papillae Eteone cf. delta Wu \& Chen, 1963 Pharyngeal surface distally with rows of swollen papillae.... 3 Pharynx with five distal rows of swollen papillae

Hypereteone barantollae (Fauvel, 1932)

- $\quad$ Pharynx with three to four rows of swollen papillae. Body with three rows of dark spots Mysta ornata Grube, 1878 
- $\quad$ Median antenna absent

Segments 1 and 2 fused, but not forming a collar; Pharynx with small, irregularly distributed, papillae. Nereiphylla castanea (Marenzeller, 1879)

- Segment 1 covered dorsally by the posterior part of the prostomium, but not fused to segment 2; Pharynx with 12 longitudinal rows of papillae proximally and 6 rugose bands distally Phyllodoce madeirensis Langerhans, 1880

\section{Nereididae}

The pharynx is often not everted in preserved material, but the jaws and any paragnaths/ papillae present may be seen by making a mid-ventral cut backwards from the mouth, cutting through the ventral surface of the pharynx as well as the body wall for several segments, and folding the resulting flaps to the side to reveal the complete jaw apparatus.

\section{Neanthes chingrighattensis (Fauvel, 1932)}

One specimen was found. This species could be regarded as a typical nereidid, having paragnaths on the pharynx and four pairs of tentacular cirri (Fig. 3). The arrangement of the paragnaths agrees with that depicted by Fauvel (1953). Falcigerous chaetae are entirely absent in this species. It is a new record for Bangladesh according to Pramanik et al. (2009). The type locality is Kolkata, West Bengal, and Misra (1999) states that the species is endemic in Indian waters.

\section{Lycastonereis indica Rao, 1981}

This species has no paragnaths on the pharynx and only three pairs of tentacular cirri (Fig. 4). It is, however, not a member of the genus Namanereis because it has parapodia with two distinct branches (notopodium and neuropodium) each with chaetae. Members of Namanereis only have one parapodial lobe with chaetae. This species is not mentioned in Pramanik et al. (2009) but is recorded by Alam et al. (1996) as common on the Halishahar Coast and Misra (1999) states that the species is endemic in northeast coast of India. It is relatively common here, with nine specimens found.

\section{Discussion of Northern Bay of Bengal Nereididae}

Pramanik et al. (2009) record 12 species of nereidid from Bangladesh: Dendronereides heteropoda, Dendronereis aestuarina, Dendronereis arborifera, Lycastis indica, Namanereis quadraticeps, Nereis caudata, Nereis falcaria, Nereis lamellosa, Nereis mossambica, Nereis operta, Tylonereis bogoyawlenskyi (sic) and Tylonereis fauveli. Alam et al. (1996) add Perinereis nuntia as well as Lycastonereis indica to this list. 


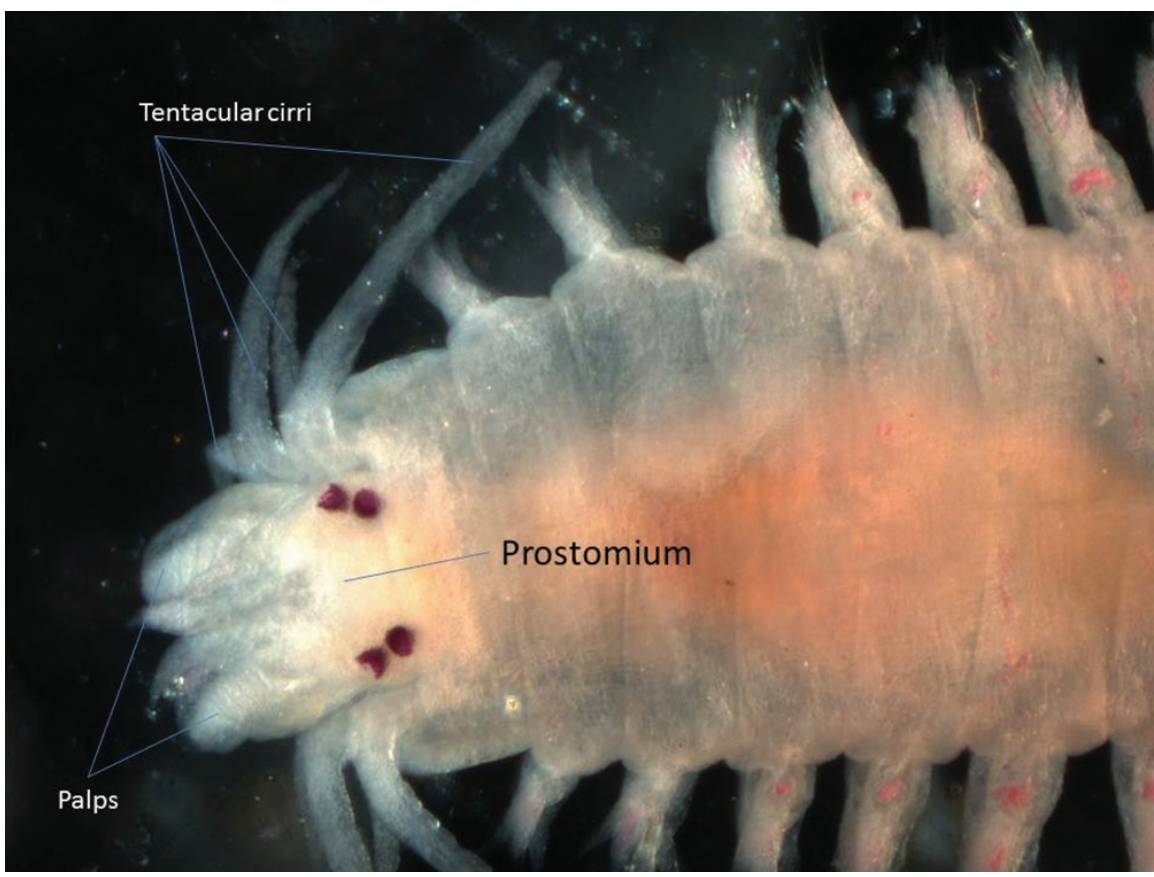

Figure 3. Dorsal view of anterior end of Neanthes chingrighattensis.

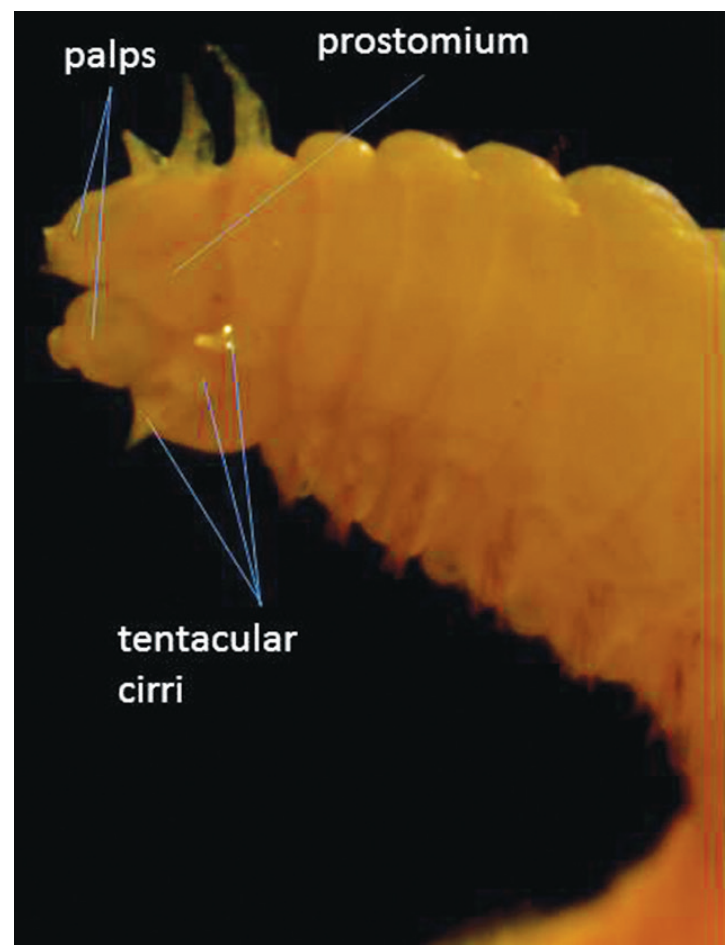

Figure 4. Dorsal view of anterior end of Lycastonereis indica. 
The collections from Myanmar in the Natural History Museum, London, include: NHMUK ANEA 1933.3.18.43, NHMUK ANEA 1937.1.4.16-42 Ceratonereis burmensis Monro, 1937, Types; NHMUK ANEA 1931.6.22.70, NHMUK ANEA 2014.7 Namalycastis abiuma species group; NHMUK ANEA 1931.6.22.67-69 Namalycastis multiseta Glasby, 1999, Types; NHMUK ANEA 1931.6.22.71-73 Neanthes meggitti Monro, 1931, Types; NHMUKANEA 1933.3.18.5-14, NHMUKANEA 1935.1.31.6, NHMUK ANEA 1935.1.31.7-8 Nereis falcaria; NHMUK ANEA 1933.3.18.1516 Nereis sp.; NHMUK ANEA 1933.3.18.1-4, NHMUK ANEA 1937.3.10.10-11 Nereis zonata; NHMUK ANEA 1937.3.10.12 Perinereis cultrifera?; NHMUK ANEA 1937.1.4.43-44 Perinereis nuntia; NHMUK ANEA 1932.11.25.5, NHMUK ANEA 1937.1.4.45-66 Perinereis singaporiensis; NHMUK ANEA 1932.11.25.2-3, NHMUK ANEA 1933.3.18.44-46, NHMUK ANEA 1935.1.31.16-18, NHMUK ANEA 1937.1.4.67-68 Pseudonereis trimaculata; NHMUK ANEA 1933.3.18.32-33 Tylonereis bogoyawlenskyi. Fauvel 1932 records Leonnates jousseaumei (from the Mergui Archipelago, shore collecting), Lycastis meraukensis (from Mergui), Nereis onychophora (from the Jack and Una Islands, Mergui Archipelago, shore collecting), Perinereis cultrifera var. helleri (from Mergui), Perinereis singaporiensis (from the Jack and Una Islands, shore collecting) and Tylonereis fauveli (from Mergui harbour, 7 fathoms).

Chandra and Chakraborty (2008), Das et al. (2009), Khan (2003), Misra (1999), Mitra and Misra (2010), Nesemann et al. (2007), Paul and Nandi (2003) and Sarkar et al. (2005) record 18 species (and one variety) of nereidid from coasts, estuaries, rivers and wetlands in West Bengal: Ceratonereis burmensis, Dendronereides gangetica, Dendronereides heteropoda, Dendronereis aestuarina, Dendronereis dayi, Ganganereis sootai, Lycastonereis indica, Namalycastis fauveli, Namalycastis indica, Namalycastis merankensis, Neanthes chilkaensis, Neanthes chingrighattensis, Neanthes glandicincta, Neanthes meggitti, Perinereis cavifrons, Perinereis cultrifera, Perinereis nigropunctata, Perinereis nuntia, Perinereis nuntia var. typica.

Misra (1999), Mitra et al. (2010), Rao (1995) and Soota and Rao (1977) record 17 species of nereidid from coasts, estuaries, the Baitarani River and Chilka Lake in Odisha: Ceratonereis burmensis, Dendronereides gangetica, Dendronereides heteropoda, Dendronereis aestuarina, Dendronereis dayi, Leonnates persica, Lycastonereis indica, $\mathrm{Na}$ malycastis fauveli, Namalycastis indica, Neanthes chingrighattensis, Nereis (Neanthes) chilkaensis, Nereis (Neanthes) glandicincta, Neanthes glandicincta, Nereis (Neanthes) reducta, Nereis (Neanthes) willeyi, Nereis (Nereis) persica, Perinereis cultrifera and Perinereis nigropunctata.

Many of these species have had their names changed for taxonomic reasons, or are otherwise worthy of comment.

The genus Ceratonereis has been revised by Hartmann-Schröder (1985), who places the species Ceratonereis burmensis in the subgenus Composetia. Composetia has now been raised to generic level, but more work is needed on this grouping (Bakken and Wilson 2005).

Leonnates jousseamei has been synonymised with $L$. indicus by Qiu and Qian (2000), who also correct $L$. persica to $L$. persicus. 
Glasby (1999) states that Namanereis quadraticeps is restricted to the Subantarctic and temperate shores of the Southern hemisphere, and Glasby et al. (2009) refer it to the Namanereis quadraticeps (Blanchard in Gay, 1849) species group.

Glasby (1999) accepts Lycastis indica as a member of the genus Namalycastis, and also places Namalycastis meraukensis in the Namalycastis abiuma (Grube, 1872) species group.

Nereis falcaria was reduced to a subspecies of Nereis jacksoni by HartmannSchröder (1974) but the two species were separated again by Wu et al. (1981, see Wu et al. 1985). Wilson (1984) accepts Nereis caudata as a member of the genus Neanthes. Most members of the genera Neanthes and Nereis need to have their type specimens compared with the descriptions in Bakken and Wilson (2005) before their generic placement can be confirmed.

Perinereis nuntia has been studied by Glasby and Hsieh (2006), Wilson and Glasby (1993) and Yousefi et al. (2011), and as Alam et al. (1996) did not give a full description of their specimens, it would be better to refer them to the Perinereis nuntia (Savigny, 1818) species group. The specimen 1937.1.4.43-44 from Maungmagaun, Myanmar, has been studied and identified as P. nuntia as defined by Glasby and Hsieh (2006). Perinereis helleri was kept separate from Perinereis cultrifera by Hutchings et al. (1991), but was synonymised with it by Khlebovich (1996). Problems with species of Perinereis were also discussed by Muir and Bamber (2008).

The very similar species Pseudonereis trimaculata and Pseudonereis variegata have been kept separate by Bakken (2007) and Villalobos-Guerrero and Tovar-Hernández (2013). Most characters seem to overlap completely, but in $P$. trimaculata the dorsal cirrus, rather being sub-terminal, is attached to the notopodium terminally from about chaetiger 40 , and the ventral ligule of the neuropodium is $0.5-0.8$ times as long as the acicular ligule in anterior chaetigers. In $P$. variegata only the last few dorsal cirri are attached terminally, and the ventral ligule of the neuropodium is as long as the acicular ligule in anterior chaetigers (it is as long as the acicular ligule in posterior chaetigers in both species). It is not surprising, therefore, that Monro labelled sample 1932.11.25.23 in the NHM as Pseudonereis trimaculata = variegata. The four samples from Myanmar have now been re-examined, and while some are definitely $P$. trimaculata, others have the longer ventral ligule of the neuropodium in anterior chaetigers of $P$. variegata while also having the dorsal cirrus attached to the notopodium terminally in the last quarter of the body. We are treating all the Myanmar specimens as $P$. trimaculata, but mentioning both species in the key.

The relevant species mentioned above can be keyed out as follows, but any identifications must be checked against reliable descriptions as many other species are known from the Bay of Bengal and other Indo-Pacific areas.

1 Three pairs of tentacular cirri. Paragnaths absent from pharynx

Lycastonereis indica Rao, 1981

Four pairs of tentacular cirri. Paragnaths present or absent ........................ 2 

Branchiae present dorsally on some notopodia............................................4 Branchiae absent from notopodia .......................................................... 8 Cluster of branchial filaments below dorsal cirrus on about segments 8 to 40 ...5 Dorsal cirrus develops into bipinnate branchia on some middle segments... 6 Branchiae as row of simple filaments, later developing into two whorls of filaments, on segments 10-38. . Dendronereides gangetica Misra, 1999 Cluster of branched branchiae below dorsal cirrus on segments 8 to 40 Dendronereides heteropoda Southern, 1921 Chaetae include homogomph and heterogomph spinigers. Papillae present on both rings of pharynx Dendronereis dayi Misra, 1999 Chaetae all homogomph spinigers. Papillae absent or only on oral ring of pharynx

Pharyngeal papillae absent. All branchiae bipinnate. Anterior neuropodia with 5-6 lobes Dendronereis arborifera Peters, 1854 Papillae present on oral ring of pharynx. First three pairs of branchiae pectinate, the rest bipinnate. Anterior neuropodia with 10-12 lobes and an inferior ligule (number decreasing posteriorly)

Dendronereis aestuarina Southern, 1921

Parapodia clearly biramous. All chaetae spinigers

Parapodia clearly biramous. Spinigers and homogomph falcigers present....9 Parapodia with no deep separation between notopodium and neuropodium. Spinigers and heterogomph falcigers present. Body widest mid-anteriorly (chaetigers 9-20). Sub-neuroacicular chaetae heterogomph spinigers and falcigers.

Body with uniform width anteriorly, tapering in far posterior region.........13 Sub-neuroacicular chaetae heterogomph falcigers and heterogomph spinigers

Sub-neuroacicular chaetae heterogomph falcigers

Namanereis quadraticeps (Blanchard in Gay, 1849) species group Prostomium 1.3-2.3x wider than long. Usually less than 10 sesquigomph spinigers in neuropodial supra-acicular fascicle in midbody 
Prostomium 2.4x wider than long or even wider. 10-30 sesquigomph spinigers in neuropodial supra-acicular fascicle in midbody

Namalycastis multiseta Glasby, 1999

Antennae minute, not reaching tip of palpophore. Heterogomph falcigers with boss extremely prolonged. Jaw with 2-3 subterminal teeth $+2-4$ ensheathed proximally.

Namalycastis fauveli Rao, 1981

Antennae more or less reaching tip of palpophore. Heterogomph falcigers with boss not prolonged. Jaw with 2-5 subterminal teeth $+3-5$ ensheathed proximally

Namalycastis indica (Southern, 1921)

16 Groups V, VI, VII and VIII with no paragnaths

Composetia burmensis (Monro, 1937)

Groups V, VI, VII and VIII with paragnaths

All paragnaths in the shape of cones or small dots..................................22

Group VI = two transverse bars ...... Perinereis singaporiensis Grube, 1878 Groups V and VI have a continuous row of transverse bars.

Perinereis nuntia (Savigny, 1818) species group

Group I = 6-12 paragnaths in an irregular group

22 One simple falciger present in posterior notopodia

Nereis onychophora Horst, 1918

Compound notopodial falcigers present posteriorly

23 Groups VII and VIII as a single row except in juveniles where it may be double Nereis falcaria (Willey, 1905)

Groups VII and VIII as an irregular band two to four deep .....

24 Apices of notopodial falcigers with 1-3 large teeth... Nereis persica Fauvel, 1911 Apices of notopodial falcigers smooth or lightly serrate.

25 Group I $=0$, Group III $=5$ in single transverse row, Groups VII and VIII $=$ a broad band with an anterior row of large paragnaths and two to three posterior rows of smaller ones

Nereis jacksoni Kinberg, 1866 Group I = 1-3, Group III = 12-22 in a transverse group, Groups VII and VIII $=2$ rows, the posterior with smaller, more numerous paragnaths.....

Group I = 1-3, Group III = about three rows totalling 20-30, Groups VII and VIII $=$ three or four irregular rows Nereis lamellosa Ehlers, 1868 Falcigerous chaetae entirely absentNeanthes chingrighattensis Fauvel, 1932 
- $\quad$ Some falcigers present in neuropodia .....................................................27

27 Paragnaths of basal ring forming a continuous band which is broad ventrally... 28 Paragnaths of V and VI separate, Groups VII and VIII forming a band 2-4 deep Neanthes willeyi (Day, 1934) Paragnaths of V absent, Groups VII and VIII forming a band of one to three rows

28 Group I = 1 paragnath Neanthes operta Stimpson, 1856 Group I = 4-12 paragnaths, which may be small.

29 Groups V, VI, VII and VIII form a complete broad band of several rows of paragnaths Neanthes caudata (Chiaje, 1841)

- $\quad$ Group V = 4-6 rather large paragnaths, Group VI = 5-6 paragnaths in a round cluster, Groups VII and VIII form 3-4 irregular rows of very large and small cones

Neanthes meggitti Monro, 1931

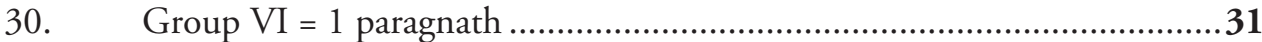

- $\quad$ Group VI = several paragnaths (may be minute) .........................................32

31 Group VI = 1 paragnath; Group IV = 6-12 large paragnaths

Neanthes glandicincta (Southern, 1921)

- $\quad$ Group VI = 1 large, oval, paragnath; Group IV = a wedge of about 20 paragnaths. Neanthes mossambica Day, 1957

32 Group I = 6-10 paragnaths, Group II = 18-20 paragnaths, Group III = a transverse band of 3-4 rows of paragnaths

Neanthes chilkaensis (Southern, 1921)

- $\quad$ Group I = 1 paragnath, Group II = 6 paragnaths, Group III = 11 paragnaths

Neanthes reducta (Southern, 1921)

33 Group $V=1-3$ paragnaths. Neuropodia of anterior chaetigers with ventral ligule shorter than the acicular ligule. Dorsal cirrus attached terminally in the last quarter of the body

Pseudonereis trimaculata Horst, 1924

- $\quad$ Group V = 1 paragnath. Neuropodia of anterior chaetigers with ventral ligule as long as the acicular ligule. Dorsal cirrus terminal in the last few chaetigers only

Pseudonereis variegata (Grube, 1857)

\section{Lumbrineridae}

The Lumbrineridae used to be regarded as part of the family Eunicidae (e.g. Fauvel (1953), Day (1967)), but is now regarded as a separate family alongside the Eunicidae and various others in the Order Eunicida (see George and Hartmann-Schröder (1985), Carrera-Parra (2006a)).

The pharynx is usually not everted in preserved material, but the maxillae may be seen by making a lateral cut (not a mid-ventral cut as used for nereidids) backwards from the side of the mouth, cutting through the side of the pharynx as well as the body wall for several segments, and folding the resulting flap to the side to reveal the complete jaw apparatus. If it is necessary to dissect the pharynx in this way, the anterior chaetae should be studied first. 


\section{Gesaneris malayensis (Rullier, 1969)}

Six specimens of this species (Fig. 5) were found. The species, originally published as Lumbriconereis malayensis, was redescribed by Carrera-Parra (2006a) and transferred to a new genus. It is a new record for Bangladesh according to Pramanik et al. (2009). It is very similar to the description of Eranno papillifera (Fauvel, 1918) by Oug (2002). This latter species was also first published as a Lumbriconereis species. The most important difference is that in Gesaneris the maxillary apparatus has four pairs of maxillae, whereas in Eranno there are five pairs of maxillae.

\section{Discussion of Northern Bay of Bengal Lumbrineridae}

Previous records of lumbrinerids in Bangladesh are Lumbrinereis heteropoda heteropoda (Marenzeller, 1879) and Lumbrinereis tetraura (Schmarda, 1861), recorded by Alam et al. (1996) and Pramanik et al. (2009).

The collections of the Natural History Museum, London, contain a previously unpublished specimen (NHMUK ANEA 1937.3.10.15) collected by Prof. F.J. Meggitt at Maungmagaun, Myanmar, which can be identified using the key in Fauvel (1953) as Lumbriconereis sphaerocephala. This species has not been re-studied by recent taxonomists but it is similar to Lumbrineris inflata Moore, 1911 (see Carrera-Parra 2006b).

Das et al. (2009) record Lumbrineris heteropoda, L. polydesma and L. notocirrata from West Bengal.

In Odisha, the species Lumbrineris heteropoda, Lumbrineris notocirrata and Lumbrineris polydesma have been recorded from coasts and estuaries, while Lumbrineris polydesma and L. simplex were found in Chilka Lake (Misra 1999, Mitra et al. 2010, Rao 1995).

Lumbrineris heteropoda has been transferred to the genus Kuwaita by Carrera-Parra and Orensanz (2002) and to the genus Scoletoma by Budaeva (2005). The species appears to have a wide geographic range (Sea of Okhotsk to Red Sea) and may well be sub-divided

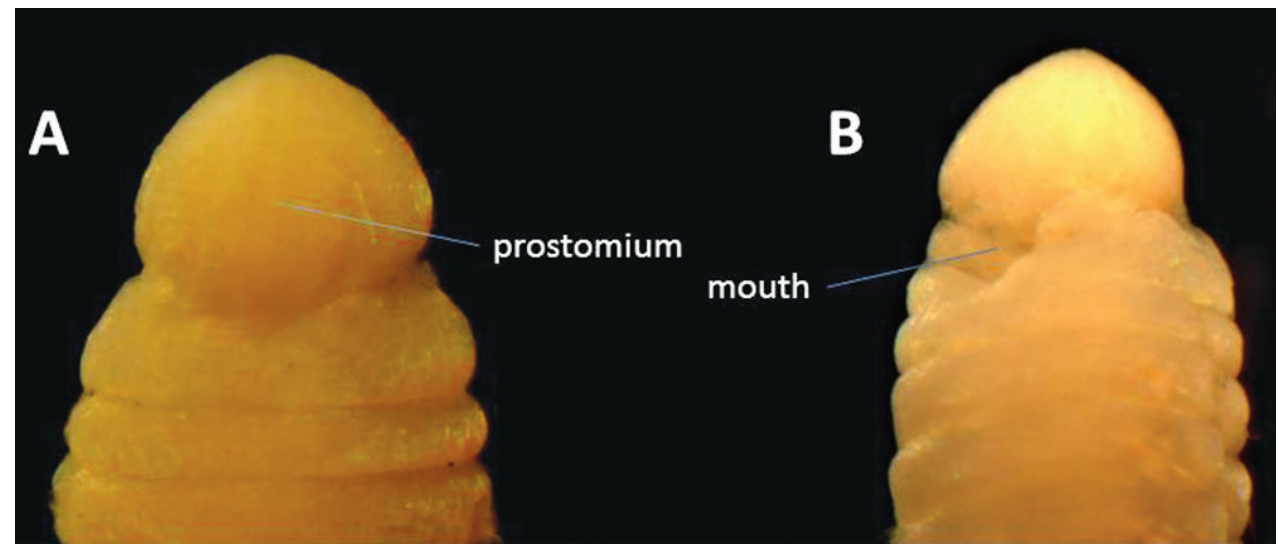

Figure 5. Anterior end of Gesaneris malayensis. A Dorsal view B Ventral view. 
after further study, but for the moment we shall accept the name Kuwaita heteropoda, as Carrera-Parra and Orensanz (2002) studied a specimen from Japan, the type locality.

Lumbrineris tetraura is accepted as a member of the genus Lumbrineris by e.g. George and Hartmann-Schröder (1985) who say it is a cosmopolitan species, but Diaz-Castaneda and Rodriguez-Villanueva(1998), place it in the genus Scoletoma, the members of which only have simple hooded hooks, whereas Lumbrineris species possess both simple and composite hooded hooks. Lumbrineris polydesma may also be better placed in the genus Scoletoma, but it is not formally transferred here because the type specimens have not been studied.

Lumbrineris simplex, having no hooked chaetae and no antennae, is better placed in the genus Arabellonereis.

Lumbrineris notocirrata has been transferred to the genus Ninoe by Fauchald (1970), because of the presence of small branchiae.

The species Lumbriconereis pseudobifilaris Fauvel, 1932, has been recorded from 250 fathoms (about $450 \mathrm{~m}$ ) depth off Akyab, Myanmar (Fauvel 1932), and from a sewage-fed fish culture pond near Calcutta, West Bengal, India (Mitra and Roy 2010). This species has no hooked chaetae but it does have two very long maxillary carriers. It is not included in the key because these characters make it a member of the family Oenonidae.

Lumbrinereis and Lumbriconereis are incorrect spellings of the generic name Lumbrineris. The northern Bay of Bengal ecoregion species of Lumbrineridae can be keyed out as follows, but any identifications must be checked against reliable descriptions as many other species are known from the Bay of Bengal and other Indo-Pacific areas.

1 Three antennae present Kuwaita beteropoda (Marenzeller, 1879)

- Antennae absent Hooded hook chaetae absent ...... Arabellonereis simplex (Southern, 1921) Hooded hook chaetae presen 3 Simple hooded hooks only. Compound hooded hooks present anteriorly, as well as simple hooded hooks along the body.... Lumbrineris sphaerocephala (Schmarda, 1861) Lateral mouth pads present. Branchiae present in posterior part of body, as a small dorsal knob or transparent vesicle, a little above the base of the parapodium Ninoe notocirrata (Fauvel, 1932)

- $\quad$ Lateral mouth pads absent. Branchiae absent .5 Hooks start about chaetiger 29 or 30 ... Lumbrineris polydesma Southern, 1921 Hooks start about chaetiger 1-4 Maxillary apparatus with five pairs of maxillae. Maxilla IV completely pigmented. Hooks with entire main tooth and crest of smaller teeth above it....

- Maxillary apparatus with four pairs of maxillae. Maxilla IV with whitish central area. Hooks with furcate main tooth and crest of smaller teeth above it.. 


\section{Glyceridae}

A posterior fragment of a glycerid was found in this collection, but it is unidentifiable to species. It is, however, a new record for Bangladesh because the fragment appears to bear branchiae on the parapodia, whereas Glycera lancadivae Schmarda, 1861, the only species in Pramanik et al. (2009), does not. Böggemann (2002) says that Glycera lancadivae is a nomen dubium, but similar to Glycera brevicirris (known from Sri Lanka and the Andaman Sea) and Glycera tesselata (nearest known localities Xisha Islands and Madagascar).

The collections of the Natural History Museum, London, contain a specimen of Glycera cinnamomea (NHMUK ANEA 1938.5.7.45) which was collected from Investigator station 549, at a depth of $24 \mathrm{fms}(43.89 \mathrm{~m})$, off Mergui Harbour (= Myeik, near the mouth of the Tanintharyi river, Myanmar), identified by Böggemann (2002). Fauvel (1932) records Glycera cirrata (from off Tenasserim, Burma, 50 fathoms (91.44 $\mathrm{m})$ ). Böggemann (2002) says this species is mixture of Glycera brevicirris (known from Sri Lanka and the Andaman Sea) and Glycera americana (nearest known localities on the coasts of South America).

Das et al. 2009 record Glycera convoluta and G. rouxii from West Bengal.

Glycera convoluta, Glycera lancadivae, Glycera longipinnis, Glycera rouxii, and Glycera tesselata have been reported by Misra (1999) and Mitra et al. (2010) from the coasts and estuaries of Odisha. According to the major revision by Böggemann (2002), $G$. convoluta is probably a junior synonym of $G$. tridactyla, $G$. lancadivae is a nomen dubium, $G$. longipinnis is a junior synonym of $G$. sphyrabrancha, $G$. rouxii is probably a junior synonym of $G$. unicornis, and $G$. tesselata is a good species. Glycinde oligodon Southern, 1921, has also been reported from the Chilka Lake, Odisha, as a glycerid by Rao (1995), but this species belongs to the family Goniadidae.

Böggemann (2002) accepts 14 species of glycerid from the Bay of Bengal area. The following key to these 14 species plus $G$. tesselata and G. unicornis (not previously recorded from the Bay of Bengal) is derived from Böggemann (2002), which contains full descriptions of these and many other species from the Indo-Pacific region.

All parapodia uniramous, notopodia absent. Ailerons rod-like

Hemipodia simplex (Grube, 1857)

- $\quad$ Parapodia biramous after (usually) first two, notopodia with simple capillary chaetae. Ailerons with a more or less triangular or deeply incised base ........2 Proboscideal papillae without terminal fingernail structure .3

- $\quad$ Proboscideal papillae with terminal fingernail structure ……………..........

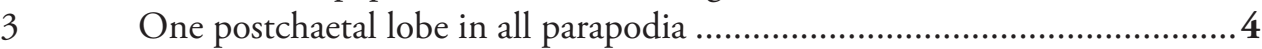

- $\quad$ Two postchaetal lobes at least on parapodia of mid-body..............................6

4 In mid-body, notopodial prechaetal lobes shorter than neuropodial lobes. Branchiae absent ............................... Glycera lapidum Quatrefages, 1866

- In mid-body, prechaetal lobes of about same length or notopodial lobes longer. Branchiae present or absent 
Digitiform proboscideal papillae without ridges. Ailerons with deeply incised bases. Simple digitiform branchiae situated termino-dorsally on parapodia...

Glycera sphyrabrancha Schmarda, 1861

Conical proboscideal papillae with about 5-20 transverse ridges. Ailerons with slightly arched bases. Branchiae absent Glycera oxycephala Ehlers, 1887 Ailerons with deeply incised bases. Postchaetal lobes short, rounded. Branchiae absent.

Ailerons with interramal plate and triangular bases. Parapodia of mid-body with slender triangular notopodial and distinctly shorter rounded neuropodial postchaetal lobes. Retractile branchiae situated medially on anterior side of parapodia.

Digitiform proboscideal papillae with straight, median, longitudinal ridge...

Glycera tesselata Grube, 1863

Digitiform proboscideal papillae with about 6-20 transverse ridges

Glycera brevicirris Grube, 1870

Parapodia with slender triangular notopodial and distinctly shorter, rounded, neuropodial postchaetal lobes; simple digitiform retractile branchiae

Glycera nicobarica Grube, 1868

Parapodia with two slender triangular postchaetal lobes of about same length or notopodial lobes only slightly longer than neuropodial lobes; digitiform retractile branchiae with $1-2$ rami

Glycera unicornis Savigny, 1818 Parapodia of mid-body with two slender triangular postchaetal lobes of about same length.....

Parapodia of mid-body with slender triangular notopodial and shorter, more or less rounded, neuropodial postchaetal lobes

Parapodia without branchiae

Glycera onomichiensis Izuka, 1912 1-5 digitiform branchial rami situated dorsally on parapodial bases.

Glycera cinnamomea Grube, 1874

In mid-body and posterior parapodia neuropodial postchaetal lobes more or less rounded. Simple digitiform branchiae situated termino-dorsally on parapodia

In posterior parapodia neuropodial postchaetal lobes as long as notopodial lobes and equally slender triangular. Simple digitiform branchiae situated medio-dorsally on parapodia...... Glycera posterobranchia Hoagland, 1920 All biramous parapodia with two postchaetal lobes. Proboscideal papillae with long, medium or short stalk

In anterior parapodia only one, medially inserted slender triangular postchaetal lobe. Proboscideal papillae with short stalk

Glycera macrobranchia Moore, 1911

Proboscideal papillae with long stalk.

Proboscideal papillae with medium-length or short stalk

Stalk without ridges. Ailerons with pointed triangular bases 
- $\quad$ Stalk with numerous ridges. Ailerons with triangular bases

Glycera natalensis Day, 1957

15 Proboscideal papillae with short stalk. Prostomium consisting of about 11-15 rings. Ailerons with triangular bases........ Glycera tridactyla Schmarda, 1861

- $\quad$ Proboscideal papillae with medium-length stalk. Prostomium consisting of about 19-28 rings. Ailerons with pointed triangular bases

Glycera africana Arwidsson, 1899

\section{Nephtyidae}

\section{Micronephthys oligobranchia (Southern, 1921)}

The single $6.5 \mathrm{~mm}$ long worm found (Fig. 6) is probably this species, which has been well described by Imajima (1987) under the name Nephtys oligobranchia. The species has been transferred to the genus Micronephthys by Dnestrovskaya and Jirkov (2010), although they say the family needs to be fully reviewed. Glasby et al. (2009) list $N$. oligobranchia as a freshwater- and saltwater-tolerant species, found in the Palaearctic and Oriental regions inhabiting lake/river freshwater, estuary and coastal lagoons (fresh-brackish) including supra-littoral areas and inland lakes. Shen and Qi (1982) say it is "favored in normal or rich trophic waters", as opposed to over-trophic or polluted waters.

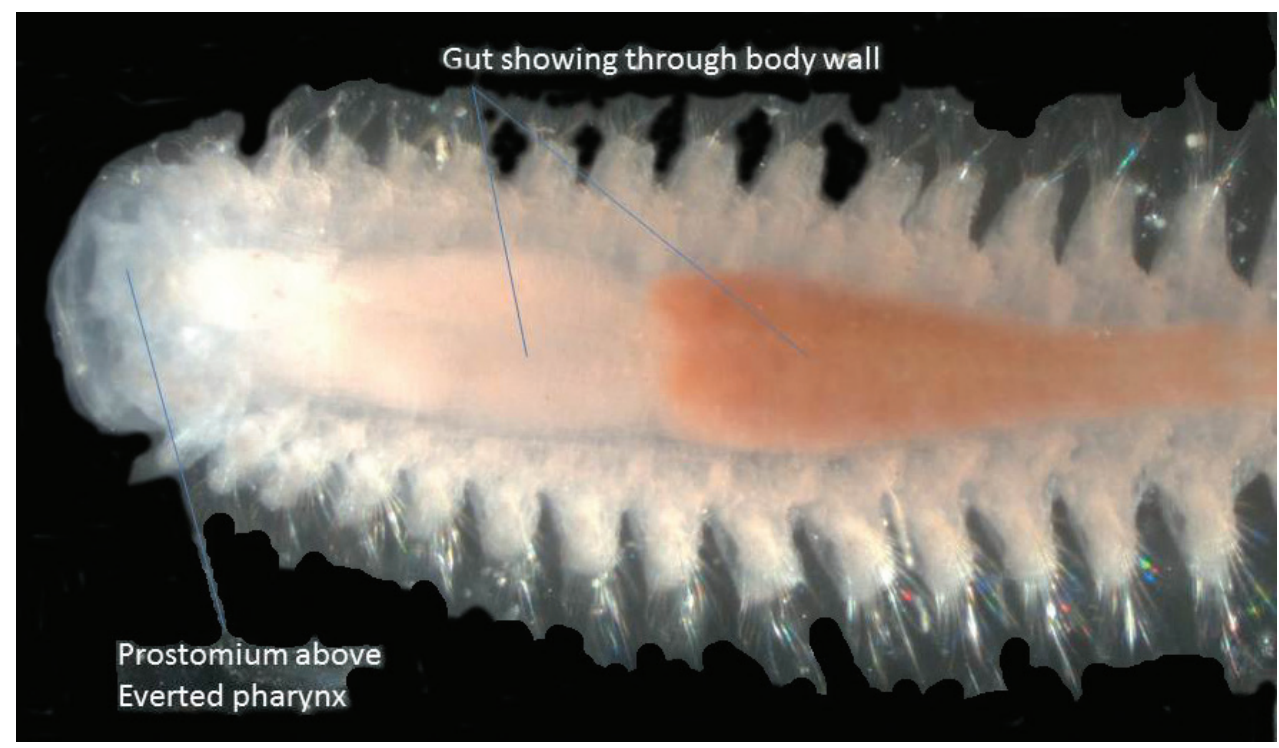

Figure 6. Dorsal view of semi-transparent specimen of Micronephtys oligobranchia with partially everted pharynx. 


\section{Discussion of Northern Bay of Bengal Nephtyidae}

Nephtys oligobranchia is the only nephtyid recorded by Pramanik et al. (2009) from Bangladesh. It is also recorded by Fauvel (1932) from Mergui, Myanmar.

$N$. oligobranchia and $N$. polybranchia Southern, 1921, have both been recorded from West Bengal (Misra 1999) and the Ganges river system (Nesemann et al. 2007). Das et al. (2009) record $N$. dibranchis and $N$. oligobranchia. Nephtys dibranchis was placed in the genus Aglaophamus by Hartman (1950).

Nephtys oligobranchia is recorded from the Baitarani River, Odisha, by Misra (1999). Nephtys oligobranchia and N. polybranchia are both recorded from the Chilka Lake (Misra 1999, Mitra et al. 2010).

The northern Bay of Bengal ecoregion species of Nephtyidae can be keyed out as follows, but any identifications must be checked against reliable descriptions as many other species are known from the Bay of Bengal and other Indo-Pacific areas.

1 Interramal cirri (branchiae) large and curving in towards the body, especially anteriorly .....................................Aglaophamus dibranchis (Grube, 1878)

- Interramal cirri poorly developed ..................................................... 2

2 Interramal cirri absent from posterior half of body

Micronephtys oligobranchia (Southern, 1921)

- $\quad$ Interramal cirri continuing more or less to end of body

Nephtys polybranchia Southern, 1921

\section{Capitellidae}

Specimens of Capitellidae, having no head appendages and usually no obvious parapodial lobes, can easily be mistaken for oligochaetes (e.g. Stephenson 1908, 1910). Without studying the reproductive system in detail, the most useful distinguishing character is the presence of hooked chaetae with a terminal hood covering the hook, which are found on the abdomen of capitellids (absent from oligochaetes).

\section{Heteromastus filiformis sensu Day}

Green (2002) gives a key to members of the genus Heteromastus found in the Indian Ocean. Unfortunately, there are variations in the descriptions of Heteromastus filiformis (Claparède, 1864) specimens described by different people. The three specimens found in this collection (Fig. 7), having expanded neuropodial lobes in the posterior abdomen and abdominal hooded hook chaetae with three teeth above the main fang, are more like those described by Day (1967) than those described by Hutchings and Rainer (1981), which had expanded notopodial lobes in the posterior abdomen 


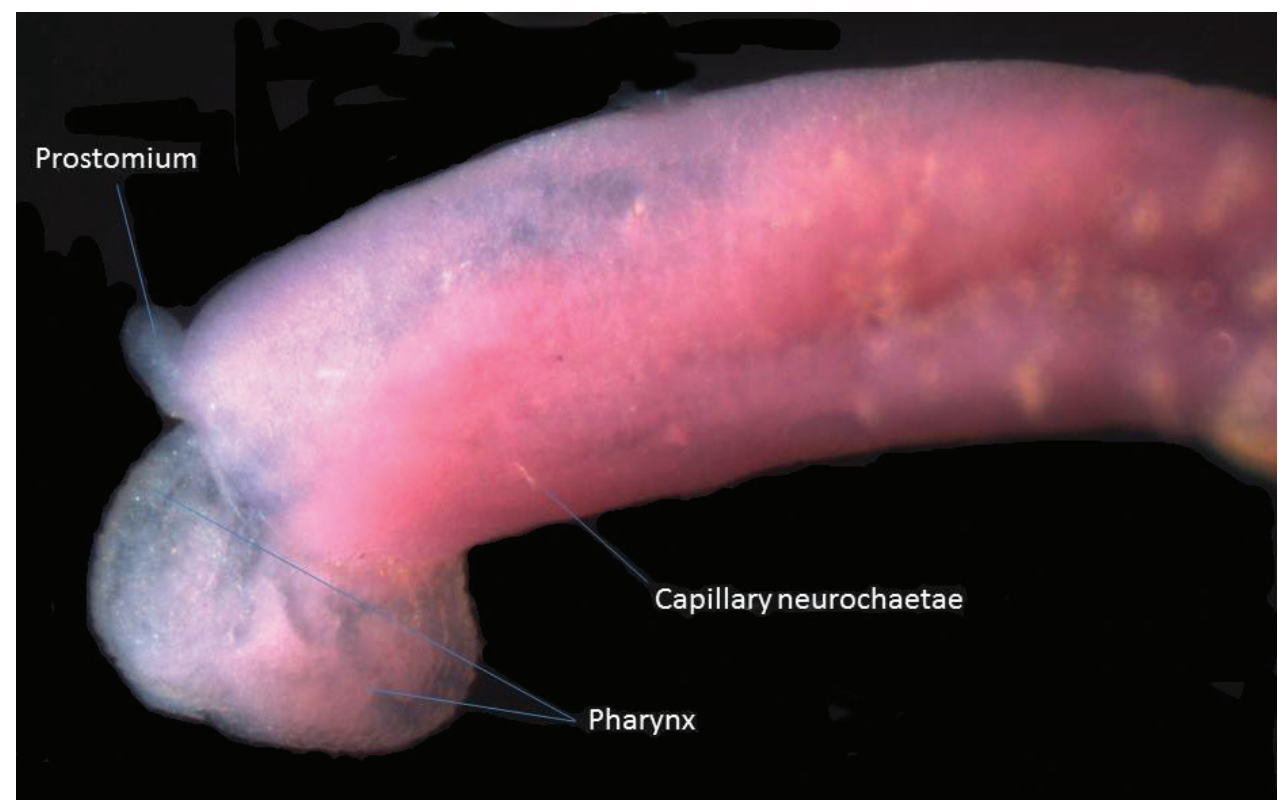

Figure 7. Lateral view of anterior end of Heteromastus fliformis with everted pharynx.

and abdominal hooded hook chaetae with 11-13 teeth above the main fang. The type locality of $H$. filiformis is in the Mediterranean (see Green 2002), so Day's specimens from South Africa could be a different species to Claparède's. Glasby et al. (2009) list Heteromastus filiformis as freshwater tolerant, but say that multiple species may have been reported under this name.

This is a new record according to Pramanik et al. (2009).

\section{Discussion of Northern Bay of Bengal Capitellidae}

Pramanik et al. (2009) give Dasybranchus caducus as the only capitellid species they know from Bangladesh.

The Natural History Museum, London, has a specimen of Notomastus near latericeus Sars, 1851 sensu Green 2002 (NHMUK ANEA 1933.3.18.71) and the type specimens of Parheteromastus tenuis Monro, 1937, from Maungmagaun, Myanmar (NHMUK ANEA 1937.1.4.151-163).

Matla bengalensis Stephenson, 1908, was described as a new genus and species of oligochaete from West Bengal, but is now (Stephenson 1910) recognised as a capitellid polychaete similar to Capitella capitata. Alam et al. (2010), Chandra and Chakraborty (2008), Das et al. (2009), Misra (1999), Mitra and Misra (2010) and Sarkar et al. (2005) report Barantolla sculpta Southern, 1921, Capitella capitata (Fabricius, 1780), Mastobranchus indicus Southern, 1921, and Parheteromastus tenuis Monro, 1937, from coasts, mangroves, lakes and rivers of West Bengal. 
In Odisha, five species of capitellid have been reported (Rao 1995), all of them from the Chilka Lake - Barantolla sculpta, Capitella capitata, Heteromastus similis, Notomastus latericeus and Pulliella armata. Magalhães and Bailey-Brock (2012) consider Pulliella to be a junior synonym of Scyphoproctus.

There follows a key to the reported species of capitellid from the Northern Bay of Bengal ecoregion, but any identifications must be checked against reliable descriptions as many other species are known from the Bay of Bengal and other Indo-Pacific areas. In particular, Green (2002) suggested earlier records of Heteromastus similis may be suspect. Also, as noted above, the type locality of Capitella capitata is West Greenland (Blake 2009). In both these cases further taxonomic work is needed, including the careful study of type specimens and probably comparisons of DNA, to see whether the Bay of Bengal specimens have been misidentified and actually represent new species (see, for example, Blake (2009), Blake et al. (2009), Wu et al. (1991)).

Most keys to capitellid genera start with the number of segments in the thorax. There may be a sudden change in size or shape of the segments at the start of the abdomen, but in many cases it is easier to make a temporary whole mount of the specimen and count the segments with capillary chaetae.

1 Posterior abdominal segments with stout acicular chaetae; pygidium with two stout, conical, diverging anal cirri ...Scyphoproctus armatus (Fauvel, 1929)

- $\quad$ Posterior abdominal segments with hooded hook chaetae; anal cirri absent ... 2

2 4-7 anterior segments with capillary chaetae ................................................ 3

- 11-13 anterior segments with capillary chaetae ..........................................6

3 Thorax with 9 segments, all with chaetae...Capitella capitata (Fabricius, 1780)

- Thorax with 12 segments, the first achaetous .............................................. 4

44 anterior segments with capillary chaetae.

Parheteromastus tenuis Monro, 1937

5 anterior segments with capillary chaetae. 6 anterior segments with capillary chaetae...Barantolla sculpta Southern, 1921 Abdominal hooks with longer anterior shaft than posterior shaft (node posterior to middle of shaft), two rows of teeth above main fang; posterior abdomen with expanded notopodial lobes Heteromastus similis Southern, 1921 Abdominal hooks with longer posterior shaft than anterior shaft (node anterior to middle of shaft), three teeth above main fang; posterior abdomen with expanded neuropodial lobes.

Heteromastus filiformis (Claparède, 1864) sensu Day, 1967

11 anterior segments with capillary chaetae.

13 anterior segments with capillary chaetae.

Dasybranchus caducus (Grube, 1846)

Abdomen with anterior two or more segments with mixed fascicles of capillary chaetae and hooded hooks

Mastobranchus indicus Southern, 1921

No segments with mixed chaetal fascicles. 


\section{General discussion}

Of the seven taxa identified above, five are new records for Bangladesh. This shows that the polychaete fauna of Bangladesh is still not well known.

Some earlier records of polychaetes will have to be re-studied before the fauna list of the Bangladesh area is complete, as names will change for taxonomic or nomenclatural reasons. An example of this is the genus Talehsapia, reported from the Hooghly estuary and South 24-Parganas, West Bengal by Misra (1999) and Mitra and Misra (2010). The genus was placed in the new family Talehsapiidae Misra, 1999, but it is now known to fit into the pilargid subfamily Synelminae (see Salazar-Vallejo et al. 2001). More recently, Talehsapia has been synonymised with the genus Hermundura (see Glasby and Hocknull 2010).

It is notable that some species reported from Bangladesh have very wide reported distributions - the same species being reported from both Bangladesh and northern Europe may be the result of misidentification or an unrecognised cryptic species. It is also notable that Ghosh (2014) reports that two polychaete species first found in this ecoregion - Asychis gangeticus Fauvel, 1932 (family Maldanidae; type locality the Gangetic delta) and Pseudopolydora kempi (Southern, 1921) (family Spionidae; type locality a canal at Chingrighatta near Kolkata) - were not found by the Zoological Survey of India between 1984 and 1989, possibly due to the river flow being reduced by dams.

While the surface salinity in the open part of the Bay of Bengal oscillates from 32$34.5 \%$, in the coastal region it varies from $10-25 \%$ and at the river mouths the surface salinity decreases to $5 \%$ or even less (Banglapedia 2010). It is no surprise, therefore, that some of the species in this paper are listed by Glasby et al. (2009) as being freshwater tolerant.

Further work on the occurrance and abundance of the macrobenthic fauna and ecology of the Sitakunda coast, Chittagong, will be published in the future (Hossain and M. Belal in prep.).

\section{Acknowledgements}

AIM would like to thank Dr. Chris Glasby, of the Museum and Art Gallery of the Northern Territory, Darwin, Australia, for a useful discussion regarding Lycastonereis indica, and Ms. Lenka Neal (NHM) for her great help with taking photomicrographs. MMMH thanks Young Power Social Action (YPSA), Bangladesh, for their financial support to do this research.

\section{References}

Alam MS, Islam MA, Ali MS (1996) Abundance and ranking of the intertidal macrobenthos of Halishahar coast, Chittagong, Bangladesh. Bangladesh Journal of Zoology 24(1): 15-19. Alam MA, Gomes A, Sarkar SK, Shuvaeva OV, Vishnevetskaya NS, Gustaytis MA, Bhattacharya BD, Godhantaraman N (2010) Trace metal bioaccumulation by soft-bottom polychaetes 
(Annelida) of Sundarban mangrove wetland, India and their potential use as contamination indicator. Bulletin of environmental Contamination and Toxicology 85(5): 492-496. doi: 10.1007/s00128-010-0110-1

Alós C (2004) Familia Phyllodocidae. Fauna Iberica 25: 105-209.

Alós C, Laborda J, Núńez J, Parapar J, Besteiro C, Moreira J, San Martín G, Alonso-Zarazaga MA (2004) Apéndice 1. Nomenclatura: Lista de sinónimos y combinaciones. Fauna Iberica 25: 495-518.

Appeltans W, Bouchet P, Boxshall GA, Fauchald K, Gordon DP, Hoeksema BW, Poore GCB, van Soest RWM, Stöhr S, Walter TC, Costello MJ (2010) World register of marine species. http://www.marinespecies.org [accessed on 2010-4-01]

Bakken T (2007) Revision of Pseudonereis (Polychaeta, Nereididae). Zoological Journal of the Linnean Society of London 150: 145-176. doi: 10.1111/j.1096-3642.2007.00289.x

Bakken T, Wilson RS (2005) Phylogeny of nereidids (Polychaeta, Nereididae) with paragnaths. Zoologica Scripta 34(5): 507-547. doi: 10.1111/j.1463-6409.2005.00200.x

Banglapedia (2010) Bay of Bengal. http://www.banglapedia.org/httpdocs/HT/B_0361.HTM [accessed on 2010-3-26]

Belaluzzaman AM (1995) Ecology of the intertidal macrobenthic fauna in Cox's Bazar coastal area, Bangladesh. MSc thesis. Institute of Marine Sciences and Fisheries, University of Chittagong, Chittagong, Bangladesh.

Blake JA (2009) Redescription of Capitella capitata (Fabricius) from West Greenland and designation of a neotype (Polychaeta, Capitellidae). Zoosymposia 2: 55-80.

Blake JA, Grassle JP, Eckelbarger KJ (2009) Capitella teleta, a new species designation for the opportunistic and experimental Capitella sp. I, with a review of the literature for confirmed records. Zoosymposia 2: 25-53.

Böggemann M (2002) Revision of the Glyceridae Grube 1850 (Annelida: Polychaeta). Abhandlungen der Senckenbergischen naturforschenden Gesellschaft 555: 1-249.

Budaeva NE (2005) Lumbrineridae (Annelida: Polychaeta) from the Sea of Okhotsk. Zoologiya Bespozvonochnykh 2(2): 181-202. [In Russian]

Carrera-Parra LF, Orensanz JM (2002) Revision of Kuwaita Mohammad, 1973 (Annelida, Polychaeta, Lumbrineridae). Zoosystema 24(2): 273-281.

Carrera-Parra LF (2006a) Phylogenetic analysis of Lumbrineridae Schmarda, 1861 (Annelida: Polychaeta). Zootaxa 1332: 1-36.

Carrera-Parra LF (2006b) Revision of Lumbrineris de Blainville, 1828 (Polychaeta: Lumbrineridae). Zootaxa 1336: 1-64.

Chambers SJ, Muir AI (1997) Polychaetes: British Chrysopetaloidea, Pisionoidea and Aphroditoidea. Synopses of the British Fauna. New Series 54: 1-202.

Chandra A, Chakraborty SK (2008) Distribution, density and community ecology of macrobenthic intertidal polychaetes in the coastal tract of Midnapore, West Bengal, India. Journal of the Marine Biological Association of India 50(1): 7-16.

Chen X-W, Cai L-Z, Wu C, Peng X, Cao J, Xu P, Fu S-J (2012) Polychaete community in mangrove and salt marsh in Zhangjiang River Estuary, Fujian Province of East China. Yingyong Shengtai Xuebao 23(4): 931-938.

Claus S, De Hauwere N, Vanhoorne B, Hernandez F, Mees J (2014) Marineregions.org. http://www.marineregions.org [accessed on 2013-12-02] 
Das BC, Reynolds JW (2003) A checklist and distribution of the freshwater and terrestrial Annelida (Oligochaeta, Hirudinea and Polychaeta) of Bangladesh. Megadrilogica 9(10): 61-70.

Das P, Dhar P, Chatterjee TK, Sarma D (2009) Species diversity of polychaete fauna of Digha-Talsari region of West Bengal, India. Journal of the Inland Fisheries Society of India 41(1): 16-20.

Day JH (1967) A monograph on the Polychaeta of southern Africa. British Museum (Natural History), London, Pt. 1. Errantia: 1-458; Pt. 2. Sedentaria: 459-878.

Diaz-Castaneda V, Rodriguez-Villanueva V (1998) Polychaete fauna from San Quintin Bay, Baja California, Mexico. Bulletin of the Southern California Academy of Sciences 97(1): 9-32.

Dnestrovskaya NYu, Jirkov IA (2010) Micronephthys (Polychaeta: Nephtyidae) of Northern Europe and Arctic. Invertebrate Zoology 7(2): 107-121.

Fauchald K (1970) Polychaetous annelids of the families Eunicidae, Lumbrineridae, Iphitimidae, Arabellidae, Lysaretidae and Dorvilleidae from western Mexico. Allan Hancock Monographs in Marine Biology 5: 1-335.

Fauchald K (1977) The polychaete worms. Definitions and keys to the orders, families and genera. Natural History Museum of Los Angeles County Science Series 28: 1-190.

Fauchald K, Jumars PA (1979) The diet of worms: A study of polychaete feeding guilds. Oceanography and marine Biology annual review 17: 193-284.

Fauvel P (1923) Polychètes errantes. Faune de France 5: 1-488.

Fauvel P (1927) Polychètes sédentaires. Addenda aux errantes, archiannélides, myzostomaires. Faune de France 16: 1-494.

Fauvel P (1932) Annelida Polychaeta of the Indian Museum, Calcutta. Memoirs of the Indian Museum 12(1): 1-262.

Fauvel P (1953) Annelida Polychaeta. Fauna of India, 507 pp.

George JD, Hartmann-Schröder G (1985) Polychaetes: British Amphinomida, Spintherida and Eunicida. Synopses of the British Fauna. New Series 32: 1-221.

Ghosh AK (2014) Environmental flow in the Hugli-Matla Estuary (W. Bengal) and vanishing species. Bionotes: quarterly newsletter of a biologists confrerie 16(1): 7-8.

Glasby CJ (1999) The Namanereidinae (Polychaeta: Nereididae). Part 1, Taxonomy and Phylogeny. Records of the Australian Museum Supplement 25: 1-129. doi: 10.3853/j.08127387.25.1999.1354

Glasby CJ, Fauchald K (2000) Key to the families of Polychaeta. In: Beesley PL, Ross GJB, Glasby CJ (Eds) Polychaetes and Allies: The Southern Synthesis. Fauna of Australia. Vol. 4A Polychaeta, Myzostomida, Pogonophora, Echiura, Sipuncula. CSIRO Publishing, Melbourne, 53-61.

Glasby CJ, Hocknull SA (2010) New records and a new species of Hermundura Müller, 1858, the senior synonym of Loandalia Monro, 1936 (Annelida: Phyllodocida: Pilargidae) from northern Australia and New Guinea. Beagle 26: 57-67.

Glasby CJ, Hsieh H-L (2006) New species and new records of the Perinereis nuntia species group (Nereididae: Polychaeta) from Taiwan and other Indo-West Pacific shores. Zoological Studies 45(4): 553-577.

Glasby CJ, Timm T, Muir AI, Gil J (2009) Catalogue of non-marine Polychaeta (Annelida) of the world. Zootaxa 2070: 1-52. 
Gray JS, Elliott M (2009) Ecology of Marine Sediments: Science to Management. Second Edition. Oxford University Press, Oxford, 240 pp.

Green KD (2002) Capitellidae (Polychaeta) from the Andaman Sea. Phuket Marine Biological Center Special Publication 24: 249-343.

Hartman O (1950) Goniadidae, Glyceridae and Nephtyidae. Allan Hancock Pacific Expeditions 15(1): $1-181$.

Hartman O (1974a) Polychaetous annelids of the Indian Ocean including an account of species collected by members of the International Indian Ocean Expeditions, 1963-'64 and a catalogue and bibliography of the species from India. Journal of the marine biological Association of India 16(1): 191-252.

Hartman O (1974b) Polychaetous annelids of the Indian Ocean including an account of species collected by members of the International Indian Ocean Expeditions, 1963-1964, and a catalogue and bibliography of the species from India. Part II. Journal of the marine biological Association of India 16(2): 609-644.

Hartmann-Schröder G (1974) Zur Kenntnis des Eulitorals der afrikanischen Westküste zwischen Angola und Kap der Guten Hoffnung und der afrikanischen Ostküste von Südafrika und Mocambique unter besonderer Berücksichtigung der Polychaeten und Ostracoden. Teil II. Die Polychaeten des Untersuchensgebietes. Mitteilungen aus dem hamburgischen zoologischen Museum und Institut 68 Suppl.: 95-228.

Hartmann-Schröder G (1985) Revision der Gattung Ceratonereis Kinberg (Nereididae, Polychaeta) (mit besonderer Berücksichtigung der Arten mit eingeschnittenem Prostomium). Mitteilungen aus dem hamburgischen zoologischen Museum und Institut 82: 37-59.

Hedgpeth JW (1957) Treatise on marine ecology and paleoecology. Volume 1. Ecology. Chapter 1. Introduction. Memoir. Geological Society of America 67: 1-16. doi: 10.1130/MEM67V1-p1

Hutchings PA, Rainer S (1981) Designation of a neotype of Capitella filiformis Claparède, 1864, type species of the genus Heteromastus (Polychaeta: Capitellidae). Records of the Australian Museum 34: 373-380. doi: 10.3853/j.0067-1975.34.1982.295

Hutchings P, Reid A, Wilson R (1991) Perinereis (Polychaeta: Nereididae) from Australia, with redescriptions of six additional species. Records of the Australian Museum 43: 241-274. doi: 10.3853/j.0067-1975.43.1991.47

Imajima M (1987) Nephtyidae (Polychaeta) from Japan. II. The genera Dentinephtys and Nephtys. Bulletin of the National Science Museum, Tokyo Series A (Zoology) 13(2): 41-77.

Khan RA (2003) Biodiversity of macrobenthos on the intertidal flats of Sunderban estuarine region, India. Records of the Zoological Survey of India 101(3-4): 181-205.

Khlebovich VV (1996) Polychaetous annelids. Volume III. Polychaetes of the family Nereididae of the Russian Seas and the adjacent waters. Fauna Rossii I Sopredel'nȳkh Stran 140: 1-223. [In Russian]

Kirtley DW (1994) A review and taxonomic revision of the family Sabellariidae Johnston, 1865 (Annelida; Polychaeta). Sabecon Press. Science Series 1: 1-223.

Magalhães WF, Bailey-Brock JH (2012) Capitellidae Grube, 1862 (Annelida: Polychaeta) from the Hawaiian Islands with description of two new species. Zootaxa 3581: 1-52.

Mahmood N, Zafar M, Barua PK, Ali S (1993) Macrobenthic fauna of an aquaculture pond of Chakaria Sunderban, Bangladesh. Pakistan Journal of Scientific and Industrial Research 36(4): 156-158. 
Misra A (1999) Polychaete. Fauna of West Bengal 10: 125-225.

Mitra S, Misra A (2010) Polychaetes of the wetlands of West Bengal. Journal of Environment and Sociobiology 7(2): 141-146.

Mitra S, Misra A, Pattanayak JG (2010) Intertidal macrofauna of Subarnarekha Estuary (Balasore: Orissa). Records of the Zoological Survey of India. Occasional Paper 313: 1-135.

Mitra S, Roy M (2010) First record of Lumbrinereis pseudobifilaris Fauvel (Annelida: Polychaeta) from West Bengal, India. Records of the Zoological Survey of India 110(4): 81-82.

Monro CCA (1931) A new brackish water polychæte from Rangoon, Nereis (Neanthes) meggitti, sp.n. Annals and Magazine of Natural History 8(10): 580-585. doi: 10.1080/00222933108673445

Monro CCA (1937) On two new polychætes from the Indian Ocean. Annals and Magazine of Natural History Series 10 19: 531-538.

Muir AI, Bamber RN (2008) New polychaete (Annelida) records and a new species from Hong Kong: the families Polynoidae, Sigalionidae, Chrysopetalidae, Pilargiidae, Nereididae, Opheliidae, Ampharetidae and Terebellidae. Journal of Natural History 42(9-12): 797-814. doi: 10.1080/00222930701850455

Nesemann H, Sharma S, Sharma G, Khanal SN, Pradhan B, Shah DN, Tachamo RD (2007) Aquatic Invertebrates of the Ganga River System (Mollusca, Annelida, Crustacea [in part]). H Nesemann, Kathmandu, 263 pp.

Oug E (2002) Lumbrineridae from the Andaman Sea, Thailand, with notes on Oenonidae and Dorvilleidae (Annelida: Polychaeta). Phuket Marine Biological Center Special publication 24: 117-138.

Paul S, Nandi NC (2003) Studies on intertidal macrozoobenthos of Hugli river in and around Calcutta in relation to water and soil conditions. Records of the Zoological Survey of India. Occasional Paper 213: 1-135.

Pramanik MN, Chowdhury SH, Kabir SMH (2009) Annelida. In: Ahmad M, Ahmed ATA, Rahman AKA, Ahmed ZU, Begum ZNT, Hassan MA, Khondker M (Eds) Encyclopedia of Flora and Fauna of Bangladesh. Volume 16. Annelida, Echinodermata, Acanthocephala and Minor Phyla. Asiatic Society of Bangladesh, Dhaka, 1-91.

Qiu J-W, Qian P-Y (2000) Revision of the genus Leonnates Kinberg, 1866 (Polychaeta: Nereididae), with descriptions and comments on other species described in Leonnates. Proceedings of the Biological Society of Washington 113(4): 1111-1146.

Rao CAN (1995) Annelida: Polychaeta. In: Ghosh AK (Ed) Fauna of Chilka Lake. Zoological Survey of India, Calcutta, 319-336.

Rouse GW (2000) Classification of the Annelida and Polychaeta. In: Beesley PL, Ross GJB, Glasby CJ (Eds) Polychaetes and Allies: The Southern Synthesis. Fauna of Australia. Vol. 4A Polychaeta, Myzostomida, Pogonophora, Echiura, Sipuncula. CSIRO Publishing, Melbourne, 51-53.

Salazar-Vallejo SI, Nishi E, Angsupanich S (2001) Rediscovery of Talehsapia annandalei (Polychaeta: Pilargidae) in Songkhla Lagoon, Thailand. Pacific Science 55(3): 267-273. doi: 10.1353/psc.2001.0025

Sarkar SK, Bhattacharya A, Giri S, Bhattacharya B, Sarkar D, Nayak DC, Chattopadhaya AK (2005) Spatiotemporal variation in benthic polychaetes (Annelida) and relationships with 
environmental variables in a tropical estuary. Wetlands Ecology and Management 13(1): 55-67. doi: 10.1007/s11273-003-5067-y

Shen S-P, Qi S (1982) Fresh-water polychaetes from the Pearl River of Guangzhou. Jinan Liyi Xuebao 5(1): 66-77.

Soota TD, Rao N (1977) On some polychaetes from Orissa coast. Records of the Zoological Survey of India 73(1-4): 327-336.

Spalding MD, Fox HE, Allen GR, Davidson N, Ferdaña ZA, Finlayson M, Halpern BS, Jorge MA, Lombana A, Lourie SA, Martin KD, McManus E, Molnar J, Recchia CA, Robertson J (2007) Marine Ecoregions of the world: a bioregionalization of coastal and shelf areas. Bioscience 57(7): 573-583. doi: 10.1641/B570707

Stephenson J (1908) The fauna of brackish ponds at Port Canning, Lower Bengal. Part VIII.Preliminary description of an oligochæte worm of uncertain position. Records of the Indian Museum, Calcutta 2(1): 39-42.

Stephenson J (1910) Polychaete worms "Matla bengalensis": a correction. Records of the Indian Museum, Calcutta 5(1): 82.

Villalobos-Guerrero TF, Tovar-Hernández MA (2013) Una especie nueva de Pseudonereis (Polychaeta: Nereididae) de Mazatlán, golfo de California, incluyendo una clave para los especies del mundo. Revista Mexicana de Biodiversidad 84: 774-781. doi: 10.7550/ rmb.32657

Wilson RS (1984) Neanthes (Polychaeta: Nereididae) from Victoria with descriptions of two new species. Proceedings of the Royal Society of Victoria 96: 209-226.

Wilson RS (1988) A review of Eteone Savigny, 1820, Mysta Malmgren, 1865 and Hypereteone Bergström, 1914 (Polychaeta: Phyllodocidae). Memoirs of the Museum of Victoria 49(2): 385-431.

Wilson RS, Glasby CJ (1993) A revision of the Perinereis nuntia species group (Polychaeta: Nereididae). Records of the Australian Museum 45(3): 253-277. doi: 10.3853/j.00671975.45.1993.23

Wu BL, Chen M (1963) Some fresh-water and mixohaline water Polychaeta from China. Oceanologia et Limnologia Sinica 5(1): 18-34.

Wu B, Qian P-Y, Zhang S (1991) Morphology, reproduction, ecology and allozyme electrophoresis of three Capitella sibling species in Qingdao (Polychaeta: Capitellidae). Ophelia supplement 5: 391-400.

Wu B, Sun R, Yan D (1981) The Nereidae (polychaetous annelids) of the Chinese coast. Oceanology Press, Beijing, 228 pp. [In Chinese]

Wu B, Sun R, Yang DJ (1985) The Nereidae (polychaetous annelids) of the Chinese coast. China Ocean Press, Beijing and Springer-Verlag, Berlin, 234 pp. [English translation of Wu, Sun \& Yan, 1981]

Yousefi S, Rahimian H, Nabavi SMB, Glasby C (2011) Nereididae (Annelida: Polychaeta) from intertidal habitats in the Gulf of Oman, Iran. Zootaxa 3013: 48-64. 